\title{
Frontal Parafalcine Meningioma Presenting as Anterior Cerebral Artery Stroke
}

Luciano Silveira Basso, MD, Diego Zambonin, MD, Luiz Roberto Tomasi Ribeiro, MD, Armando Schmidt Cardoso, MD, and Paulo Valdeci Worm, MD, PhD

Neurology ${ }^{\circledR}$ 2021;96:494-495. doi:10.1212/WNL.0000000000011541
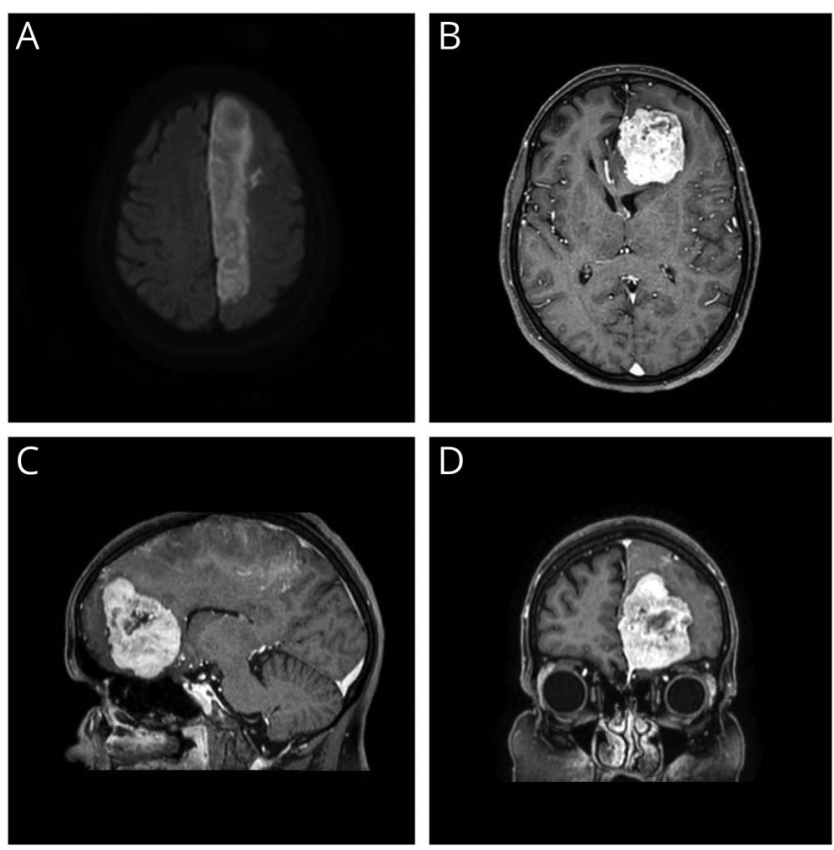

(A) Restricted diffusion in the left anterior cerebral artery territory as well as (B-D) an extra-axial lesion in the left frontal lobe with dural tail close to the olfactory groove and cerebral falx with contrast-enhanced T1-weighted image.

A 54-year-old woman presented with right grade 1 hemiparesis and aphasia (NIH Stroke Scale score 13) after 5 hours of initial symptoms. MRI revealed an ischemic area in left anterior cerebral artery territory and a left frontal tumor (figure 1). Endovascular reperfusion was unavailable. Etiologic investigation, which included ECG, echocardiogram, routine blood analysis, renal and thyroid function, lipidogram, HIV, hepatitis and syphilis antibodies, thrombophilia markers, MRI, and cerebral angiography (figure 2), did not reveal another alteration than the mechanical compression of the artery. After 2 weeks of clinical investigation and stabilization, complete surgical resection was performed. Language symptoms improved and the patient remains in rehabilitation. Exceptionally, meningiomas can compress major cerebral arteries, resulting in transient neurologic symptoms. ${ }^{1}$ Even more rarely, they can present as a stroke, with an estimated incidence of $0.19 \%{ }^{2}$

\section{Study Funding}

No targeted funding reported.

From the Department of Neurosurgery (L.S.B., D.Z., L.R.T.R., P.V.W.), Cristo Redentor Hospital; Federal University of Health Sciences of Porto Alegre (A.S.C.); and Department of Surgery (P.V.W.), Federal University of Health Sciences of Porto Alegre, Brazil.

Go to Neurology.org/N for full disclosures. Funding information and disclosures deemed relevant by the authors, if any, are provided at the end of the article. 
Figure 2 Digital Subtraction Angiography (DSA) Findings
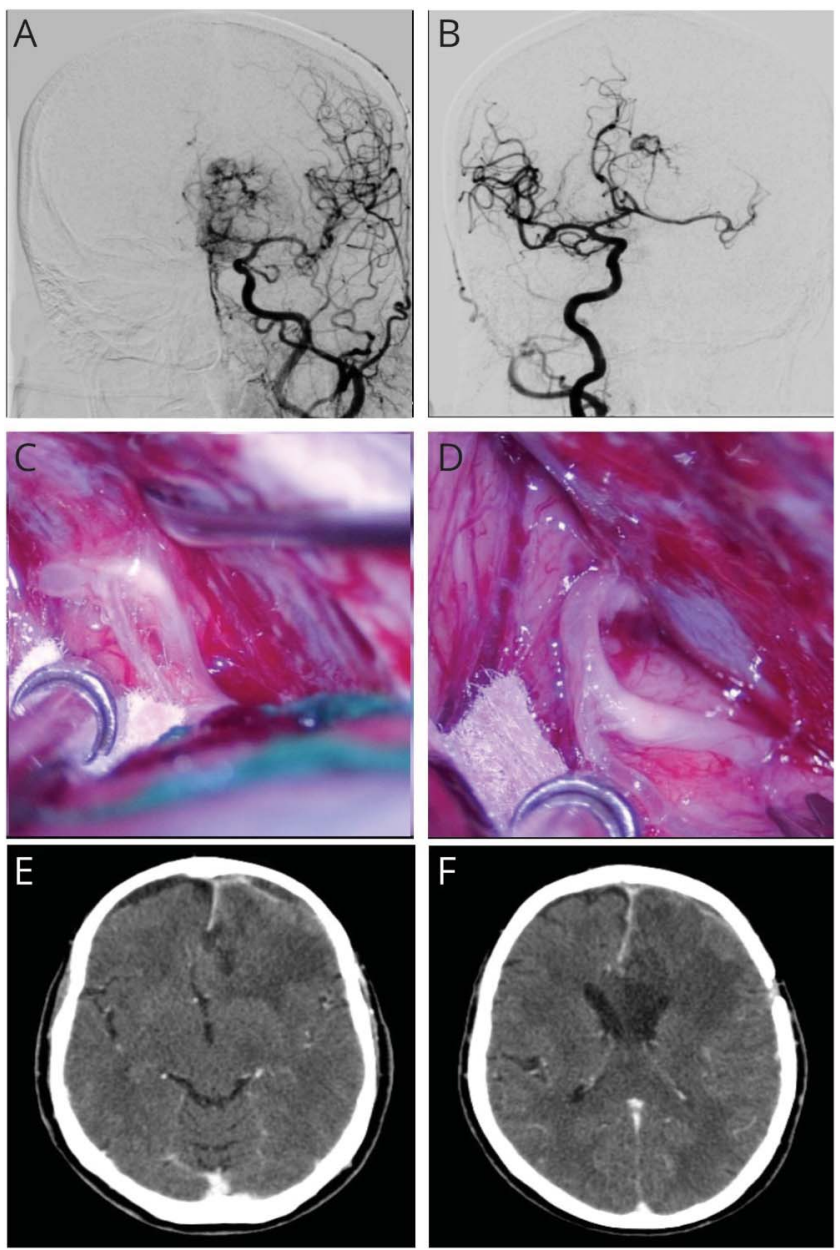

$(A, B)$ DSA shows occlusion of left anterior cerebral artery (ACA) in A2-A3 segment. (C, D) Intraoperative view shows the ACA in relation to the cerebral falx after tumor resection. (E, F) Postoperative $C T$ with contrast demonstrates total resection of the tumor.

\section{Disclosure}

The authors report no disclosures relevant to the manuscript. Go to Neurology.org/N for full disclosures.
Appendix Authors

\begin{tabular}{|c|c|c|}
\hline Name & Location & Contribution \\
\hline $\begin{array}{l}\text { Luciano } \\
\text { Silveira } \\
\text { Basso, MD }\end{array}$ & $\begin{array}{l}\text { Department of } \\
\text { Neurosurgery, Cristo } \\
\text { Redentor Hospital, Porto } \\
\text { Alegre, Brazil }\end{array}$ & $\begin{array}{l}\text { Drafting/revision of the } \\
\text { manuscript for content, } \\
\text { including medical } \\
\text { writing for content, } \\
\text { major role in the } \\
\text { acquisition of data, study } \\
\text { concept or design, } \\
\text { analysis or } \\
\text { interpretation of data }\end{array}$ \\
\hline $\begin{array}{l}\text { Diego } \\
\text { Zambonin, } \\
\text { MD }\end{array}$ & $\begin{array}{l}\text { Department of } \\
\text { Neurosurgery, Cristo } \\
\text { Redentor Hospital, Porto } \\
\text { Alegre, Brazil }\end{array}$ & $\begin{array}{l}\text { Drafting/revision of the } \\
\text { manuscript for content, } \\
\text { including medical } \\
\text { writing for content, } \\
\text { major role in the } \\
\text { acquisition of data, study } \\
\text { concept or design, } \\
\text { analysis or } \\
\text { interpretation of data }\end{array}$ \\
\hline $\begin{array}{l}\text { Luiz Roberto } \\
\text { Tomasi } \\
\text { Ribeiro, MD }\end{array}$ & $\begin{array}{l}\text { Department of } \\
\text { Neurosurgery, Cristo } \\
\text { Redentor Hospital, Porto } \\
\text { Alegre, Brazil }\end{array}$ & $\begin{array}{l}\text { Drafting/revision of the } \\
\text { manuscript for content, } \\
\text { including medical } \\
\text { writing for content, } \\
\text { major role in the } \\
\text { acquisition of data, study } \\
\text { concept or design, } \\
\text { analysis or } \\
\text { interpretation of data }\end{array}$ \\
\hline $\begin{array}{l}\text { Armando } \\
\text { Schmidt } \\
\text { Cardoso, MD }\end{array}$ & $\begin{array}{l}\text { Department of Surgery, } \\
\text { Federal University of Health } \\
\text { Sciences of Porto Alegre, } \\
\text { Brazil }\end{array}$ & $\begin{array}{l}\text { Drafting/revision of the } \\
\text { manuscript for content, } \\
\text { including medical } \\
\text { writing for content, } \\
\text { major role in the } \\
\text { acquisition of data }\end{array}$ \\
\hline $\begin{array}{l}\text { Paulo } \\
\text { Valdeci } \\
\text { Worm, MD, } \\
\text { PhD }\end{array}$ & $\begin{array}{l}\text { Department of } \\
\text { Neurosurgery, Cristo } \\
\text { Redentor Hospital and } \\
\text { Department of Surgery, } \\
\text { Federal University of Health } \\
\text { Sciences of Porto Alegre, } \\
\text { Brazil }\end{array}$ & $\begin{array}{l}\text { Drafting/revision of the } \\
\text { manuscript for content, } \\
\text { including medical } \\
\text { writing for content, } \\
\text { major role in the } \\
\text { acquisition of data, study } \\
\text { concept or design, } \\
\text { analysis or } \\
\text { interpretation of data }\end{array}$ \\
\hline
\end{tabular}

\section{References}

1. Oluigbo CO, Choudhari KA, Flynn P, McConnell RS. Meningioma presenting with transient ischaemic attacks. Br J Neurosurg 2004;18:635-637.

2. Komotar RJ, Keswani SC, Wityk RJ. Meningioma presenting as stroke: report of two cases and estimation of incidence. J Neurol Neurosurg Psychiatry 2003;74:136-137.

\section{Subspecialty Alerts by E-mail!}

Customize your online journal experience by signing up for e-mail alerts related to your subspecialty or area of interest. Access this free service by clicking on the "My Alerts" link on the home page. An extensive list of subspecialties, methods, and study design choices will be available for you to choose from-allowing you priority alerts to cutting-edge research in your field! 


\section{Neurology}

\section{Frontal Parafalcine Meningioma Presenting as Anterior Cerebral Artery Stroke}

Luciano Silveira Basso, Diego Zambonin, Luiz Roberto Tomasi Ribeiro, et al. Neurology 2021;96;494-495 Published Online before print January 27, 2021

DOI 10.1212/WNL.0000000000011541

\section{This information is current as of January 27, 2021}

\begin{tabular}{|c|c|}
\hline $\begin{array}{l}\text { Updated Information \& } \\
\text { Services }\end{array}$ & $\begin{array}{l}\text { including high resolution figures, can be found at: } \\
\text { http://n.neurology.org/content/96/10/494.full }\end{array}$ \\
\hline References & $\begin{array}{l}\text { This article cites } 2 \text { articles, } 1 \text { of which you can access for free at: } \\
\text { http://n.neurology.org/content/96/10/494.full\#ref-list-1 }\end{array}$ \\
\hline Subspecialty Collections & $\begin{array}{l}\text { This article, along with others on similar topics, appears in the } \\
\text { following collection(s): } \\
\text { Infarction } \\
\text { http://n.neurology.org/cgi/collection/infarction } \\
\text { MRI } \\
\text { http://n.neurology.org/cgi/collection/mri } \\
\text { Other cerebrovascular disease/Stroke } \\
\text { http://n.neurology.org/cgi/collection/other_cerebrovascular_disease_st } \\
\text { roke } \\
\text { Primary brain tumor } \\
\text { http://n.neurology.org/cgi/collection/primary brain tumor }\end{array}$ \\
\hline Permissions \& Licensing & $\begin{array}{l}\text { Information about reproducing this article in parts (figures,tables) or in } \\
\text { its entirety can be found online at: } \\
\text { http://www.neurology.org/about/about_the_journal\#permissions }\end{array}$ \\
\hline Reprints & $\begin{array}{l}\text { Information about ordering reprints can be found online: } \\
\text { http://n.neurology.org/subscribers/advertise }\end{array}$ \\
\hline
\end{tabular}

Neurology ${ }^{\circledR}$ is the official journal of the American Academy of Neurology. Published continuously since 1951, it is now a weekly with 48 issues per year. Copyright (C 2021 American Academy of Neurology. All rights reserved. Print ISSN: 0028-3878. Online ISSN: 1526-632X.

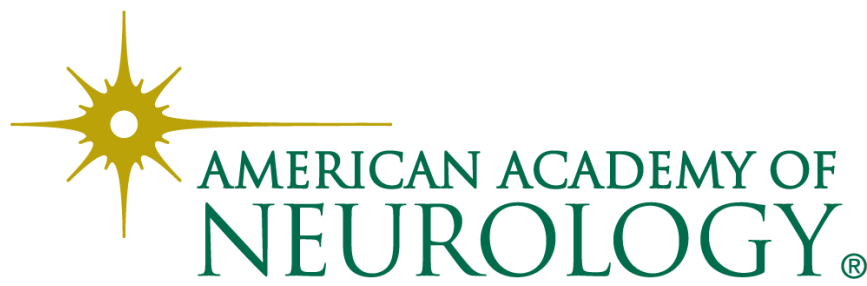

